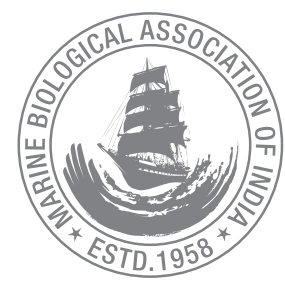

\title{
Prevalence of marine litter along the Indian beaches: A preliminary account on its status and composition
}

\author{
P. Kaladharan*, K. Vijayakumaran, V. V. Singh, D. Prema, P. S. Asha, Bindu Sulochanan, \\ P. Hemasankari, L. Loveson Edward, Shelton Padua, S. Veena, A. Anasukoya and H. M. Bhint \\ ICAR- Central Marine Fisheries Research Institute, Cochin-682 018, India.
}

*Correspondence e-mail: kaladharanep@gmail.com

Received: 21 Oct 2016, Accepted: 24 June 2017, Published: 30 June 2017

Original Article

\begin{abstract}
Beach litter are man-made objects discarded directly or indirectly. This study brings out synoptic picture of status and composition of beach litter from 254 selected beaches along the maritime States of Peninsular coast of India as well as the Union Territories of Andaman and Lakshadweep Islands from the one time observation conducted between October 2013 and January 2014 for the first time. These beaches were classified and graded with colour codes according to the levels of beach litter. Beach litter from different maritime States and the UTs showed that Odisha coast has the lowest $\left(0.31 \mathrm{~g} / \mathrm{m}^{2}\right)$ quantity and Goa coast $(205.75$ $\left.\mathrm{g} / \mathrm{m}^{2}\right)$ the highest quantity of beach debris. Archipelagic coasts of Andamans as well as Lakshadweep recorded values higher than Kerala, Tamil Nadu, Andhra Pradesh, Odisha and West Bengal. Samples of debris collected from beaches revealed that all the items were domestic and anthropogenic discards. Plastic litters such as single use carry bags and sachets of soft drinks, edible oils, detergents, beverages, cases of cosmetics, toothpaste, PET bottles, ice cream containers etc., recorded highest mean of $25.47 \mathrm{~g} / \mathrm{m}^{2}$ from Goa coast and the lowest $\left(0.08 \mathrm{~g} / \mathrm{m}^{2}\right)$ from Odisha. The relative percentage of mean values of plastic (B group) items in beach debris along the Indian coast registered highest mean percentage from Maharashtra $(81 \%)$ and the lowest mean from beaches of Andhra Pradesh (7\%). The two island Union Territories registered 40\% (Lakshadweep) and $47 \%$ (Andamans) of plastics over the total debris, while the national average was only $14 \%$.
\end{abstract}

Out of the total 254 beaches surveyed, 51 beaches were graded as very clean with green $\left(<1 \mathrm{~g} / \mathrm{m}^{2}\right)$ colour, 122 beaches were graded as Clean and depicted by blue colour. Beaches of very clean grade $\left(<1 \mathrm{~g} / \mathrm{m}^{2}\right)$ were found in Kerala (17), Maharashtra (12), Tamil Nadu (2), Andhra Pradesh (4), Odisha (7) and West Bengal (3). Whereas extremely littered beaches $\left(>100 \mathrm{~g} / \mathrm{m}^{2}\right)$ were found in Karnataka (13), Goa, Gujarat, and Andaman Island. With reference to the coastal population and per capita share of beach debris, Goa registered highest values $(40.97 \mathrm{~kg} / \mathrm{head})$ and the Odisha coast registered the lowest values $(0.005 \mathrm{~kg} / \mathrm{head})$.

Keywords: Beach litter, e-waste, coastal debris, plastic pollution, ingestion

\section{Introduction}

Solid waste management has been a great challenge to the developing nations as affluence and consumption are closely related. Increasing urbanization of coastal settlements as well as tourism development has resulted in unprecedented production 
of anthropogenic waste. Any man-made object intentionally or unintentionally discarded, disposed of, or abandoned that enters the marine environment is regarded as coastal debris. Plastic and other non-bio-degradable synthetic materials are the common groups of marine debris responsible for degradation of marine habitats and their biota. Approximately $80 \%$ of debris originates onshore and $20 \%$ from offshore sources (Allsopp et al., 2009). These waste materials are becoming a real menace and often find their way to the ultimate sink- the sea and the suspended part of which often wash ashore as litter all along the coast and those part upon sinking will persist in the sediments for many years. Apart from the beach litter, increasing quantity of marine debris including plastics and their impacts such as ingestion by or entanglement of marine biota pose serious challenge (Gregory, 2009; Sarah et al., 2016).

Coastal litter impacts in multiple ways, the most importantly they degrade the quality and health of our oceans, damage coastal and marine habitats and harm marine biota. It is estimated that about 6.4 million tons of marine litter are being disposed in to the seas annually (UNEP, 2009) and that the annual rate of production of plastic has touched 300 million tons in 2010 itself (Thompson et al., 2009). Plastics enter into the coastal and marine ecosystem either directly by illegal dumping or accidental loss of debris during fishing /cargo operations and oil rigs or indirectly by way of wind, rivers, streams, and storm drains.

Greater dependence of beaches for tourism, socio-cultural and religious activities has increased the littering in beaches. Due to our carefree lifestyle, nearly 8.8 million tonnes of plastic waste is being dumped into oceans every year. As a result over 700 species of marine organisms are in danger of extinction (Jenna et al., 2015). Levels of beach debris pollution from Korea and its main source have been studied by Hong et al. (2014). The ill effects of plastic debris on the marine environment in general have been reviewed by Derraik (2002). Rochman et al. (2013) investigated the transport of chemicals to marine biota through ingestion of plastics as well as through adsorption of organic and inorganic pollutants. Information on beach debris from India are available from various parts such as Nicobar Islands (Dharani et al., 2003), Karnataka coast (Sridhar et al., 2009), northern Gulf of Mannar (Ganesapandian et al., 2011), selected beaches of Kerala, Karnataka and Tamil Nadu (Kaladharan et al., 2012), some urban beaches in Mumbai (Jayasiri et al.,

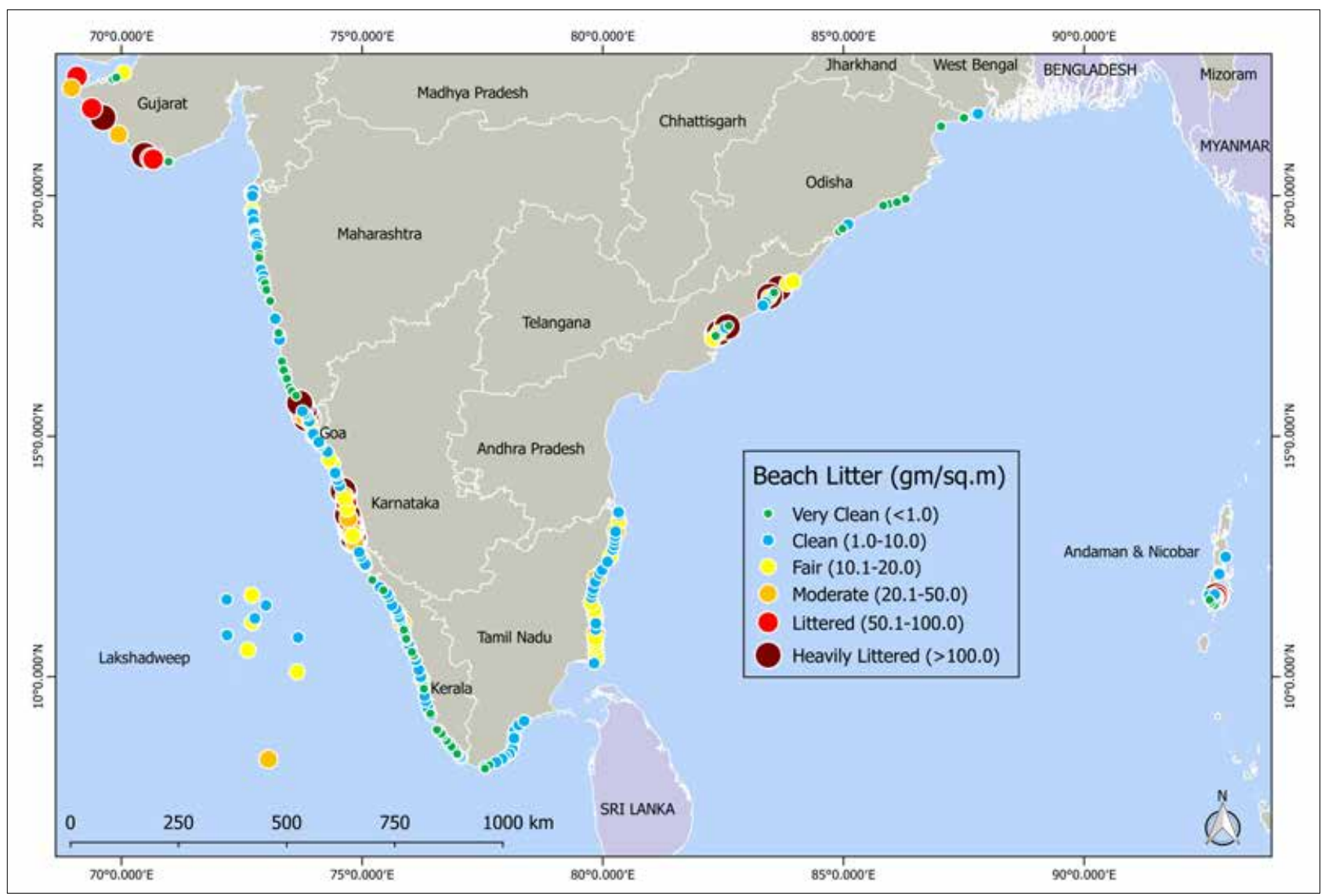

Fig.1.Study locations and their marine litter status along Indian beaches during October 2013- January 2014 
2013) and Mangalore coast (Bindu et al., 2014). However a comprehensive study of the beach debris in the country has not been undertaken so far. The present communication embodies the results on one time national survey on the quality and quantity of the non-bio degradable items found scattered on the tidal limits of certain select beaches along the coasts of Indian Peninsular and Archipelagic areas conducted during October 2013-January 2014. An attempt to classify beaches with colour code, according to the level of litter pollution is also made.

\section{Material and methods}

Along a stretch of coastline, sampling beaches were selected systematically at approximately $10 \mathrm{~km}$ intervals (Fig. 1). Sandy and open beaches with clear access to sea only were selected and those protected with seawalls and groins and blocked by jetties, breakwaters etc. were avoided for the sampling. Beach litter samples were sampled using a rope quadrate of $(10 \times 10$ $\mathrm{m}$ ) operated in triplicate from each station with $100 \mathrm{~m}$ interval on a line transect. Beach litter collected from within the three quadrates were pooled together, cleaned of adhering sand and moisture and then weighed using a top pan balance. Although extensive guidelines are available for monitoring marine litter (OSPAR, 2010) we could not assign separate ids for each debris items, instead they were sorted and grouped into six categories as shown in Table 1.

Table 1. Six categories of marine litter

\begin{tabular}{ll}
\hline Category & Materials \\
\hline A & Nylon/ HDP ropes/ fish net pieces/long lines \\
\hline B & $\begin{array}{l}\text { Plastics (covers, carry bags, sachets, PET bottles (beverages, drinking } \\
\text { water, medicine etc.), containers of milk, creams, oil, ointments, } \\
\text { toothpaste etc.) }\end{array}$ \\
\hline C & Synthetic slippers / foot wear (other than leather items) \\
\hline E & Glass bottles, electric bulbs, CFL bulbs \\
\hline F & $\begin{array}{l}\text { e-waste (TV/computer hard wares, mobile phone handsets or parts, } \\
\text { chargers, battery operated toys, CDs etc) }\end{array}$ \\
\hline
\end{tabular}

The sorted litter samples were weighed by category to know the relative composition and recorded as $\mathrm{g} / \mathrm{m}^{2}$ and numbers $/ \mathrm{m}^{2}$. Mean values $\left(\mathrm{g} / \mathrm{m}^{2}\right)$ of beach debris for each State and Union Territories were calculated using Excel software. Six colour codes were developed to grade the beaches studied from the entire coastline of India based on the mean quantity of beach debris as shown below:

\begin{tabular}{lllllll}
\hline Grade & $\begin{array}{l}\text { Very } \\
\text { clean }\end{array}$ & Clean & Fair & Moderate & Littered & $\begin{array}{l}\text { Heavily } \\
\text { littered }\end{array}$ \\
\hline Colour & & & & & & \\
\hline Mean & $<1$ & $1.1-10$ & $10.1-20$ & $20.1-50$ & $50.1-100$ & $>100$ \\
levels & $\mathrm{g} / \mathrm{m}^{2}$ & $\mathrm{~g} / \mathrm{m}^{2}$ & $\mathrm{~g} / \mathrm{m}^{2}$ & $\mathrm{~g} / \mathrm{m}^{2}$ & $\mathrm{~g} / \mathrm{m}^{2}$ & $\mathrm{~g} / \mathrm{m}^{2}$ \\
\hline
\end{tabular}

From the mean values of each State and UTs, total quantity of beach litter was calculated by multiplying with the total beach area of respective State / UTs. Beach area was calculated by multiplying the length of the coastline (ICMAM, 2010) with mean width (@20 m). Similarly per capita share of beach debris was also calculated by dividing the total quantity for the State /UTs with the respective coastal population (Marine Fisheries (ensus, 2010) without taking into account the number of tourists and visitors to the beaches.

\section{Results}

Perusal of the mean of all beach litter from different maritime States and the UTs showed that Odisha coast has the lowest $\left(0.31 \mathrm{~g} / \mathrm{m}^{2}\right)$ quantity and Goa coast $\left(205.75 \mathrm{~g} / \mathrm{m}^{2}\right)$ the highest quantity of beach debris. Karnataka coast registered second highest mean quantity $\left(178.44 \mathrm{~g} / \mathrm{m}^{2}\right)$ while Maharashtra and Kerala registered a near-equal mean of $3.8 \mathrm{~g} / \mathrm{m}^{2}$. Archipelagic coasts of Andamans as well as the Lakshadweep recorded values higher than Kerala, Tamil Nadu, Andhra Pradesh, Odisha and West Bengal (Table 2). Synoptic view of study sites and the quantity of marine litter during the study period along the Indian coast line graded with appropriate colour codes is presented in Fig.1. Samples of debris collected from beaches revealed that all the items were domestic and anthropogenic discards.

When the beach debris data were analysed by group, the pattern of distribution of different groups in different States/ UTs is summarised in Table 3. Nylon nets/ fishing lines (group A) registered highest mean $\left(75.67 \mathrm{~g} / \mathrm{m}^{2}\right)$ in Goa and the lowest mean $\left(0.01 \mathrm{~g} / \mathrm{m}^{2}\right)$ in West Bengal. Similarly the Group $B$ plastics comprising single use carry bags and sachets of soft drinks, edible oils, detergents, beverages, cases of cosmetics, toothpaste, PET bottles, ice cream containers etc., recorded highest mean of $25.47 \mathrm{~g} / \mathrm{m}^{2}$ from Goa coast and the lowest from Odisha $\left(0.08 \mathrm{~g} / \mathrm{m}^{2}\right)$, although maximum value of ' $B$ ' was

Table 2. Beach litter $\left(\mathrm{g} / \mathrm{m}^{2}\right)$ from different States and the Union Territories of India

\begin{tabular}{lllll}
\hline State/UT & Min & Max & Mean & Sample size \\
\hline Kerala & 0 & 22.2 & 3.84 & 54 \\
\hline Karnataka & 2.9 & 1240 & 178.44 & 33 \\
\hline Goa & 5 & 842 & 205.75 & 15 \\
\hline Maharashtra & 0.03 & 13.27 & 3.81 & 38 \\
\hline Gujarat & 0 & 630.5 & 90.56 & 12 \\
\hline Tamil Nadu & 0.18 & 25.4 & 8.06 & 47 \\
\hline Andhra Pradesh & 0.281 & 19.14 & 7.54 & 19 \\
\hline Odisha & 0.02 & 1.34 & 0.31 & 8 \\
\hline West Bengal & 0.537 & 2.02 & 1.01 & 5 \\
\hline Lakshadweep & 4.51 & 31.73 & 10.97 & 10 \\
\hline Andaman \& Nicobar & 0 & 159 & 19.23 & 13 \\
\hline National & 0 & 1240 & 45.86 & 254 \\
\hline
\end{tabular}


Table 3. Regional and group wise distribution of beach debris $\left(\mathrm{g} / \mathrm{m}^{2}\right)$

\begin{tabular}{|c|c|c|c|c|c|c|c|}
\hline Litter type & A & B & C & $D$ & $E$ & $\mathrm{~F}$ & others \\
\hline \multicolumn{8}{|l|}{ KERALA } \\
\hline Minimum & 0 & 0 & 0 & 0 & 0 & 0 & 0 \\
\hline Maximum & 2.5 & 5.5 & 19 & 5.5 & 0.5 & 12 & 0 \\
\hline Average & 0.21 & 0.92 & 1.48 & 0.75 & 0.01 & 0.47 & 0 \\
\hline \multicolumn{8}{|c|}{ KARNATAKA } \\
\hline Minimum & 0 & 0 & 0 & 0 & 0 & 0 & 0 \\
\hline Maximum & 40 & 150 & 600 & 650 & 10 & 670 & 18 \\
\hline Average & 6.93 & 21.91 & 57.87 & 63.55 & 0.3 & 26.47 & 1.4 \\
\hline \multicolumn{8}{|l|}{ GOA } \\
\hline Minimum & 0 & 2 & 0 & 0 & 0 & 0 & 0 \\
\hline Maximum & 543 & 110 & 139 & 500 & 10 & 93.2 & 0 \\
\hline Average & 75.67 & 25.47 & 23.43 & 68.15 & 0.67 & 13.93 & 0 \\
\hline \multicolumn{8}{|c|}{ MAHARASHTRA } \\
\hline Minimum & 0 & 0.0286 & 0 & 0 & 0 & 0 & 0 \\
\hline Maximum & 0.837 & 12.786 & 6.813 & 0.882 & 0.05 & 0.84 & 0 \\
\hline Average & 0.17 & 3.08 & 0.45 & 0.04 & 0 & 0.08 & 0 \\
\hline \multicolumn{8}{|l|}{ GUJARATH } \\
\hline Minimum & 0 & 0 & 0 & 0 & 0 & 0 & 0 \\
\hline Maximum & 173 & 76.3 & 143 & 124.4 & 0 & 113.8 & 0 \\
\hline Average & 23.1 & 12.62 & 24.44 & 20.04 & 0 & 10.35 & 0 \\
\hline \multicolumn{8}{|c|}{ TAMIL NADU } \\
\hline Minimum & 0 & 0 & 0 & 0 & 0 & 0 & 0 \\
\hline Maximum & 11.5 & 4.5 & 9 & 11 & 1.61 & 2.1 & 0 \\
\hline Average & 1.94 & 1.49 & 2.66 & 1.47 & 0.08 & 0.42 & 0 \\
\hline \multicolumn{8}{|c|}{ ANDHRA PRADESH } \\
\hline Minimum & 0 & 0.11 & 0 & 0 & 0 & 0.001 & 0 \\
\hline Maximum & 4.03 & 1.22 & 4.45 & 3.52 & 15 & 9.57 & 0 \\
\hline Average & 0.62 & 0.52 & 1.07 & 1.16 & 0.9 & 3.27 & 0 \\
\hline \multicolumn{8}{|l|}{ ODISHA } \\
\hline Minimum & 0 & 0.02 & 0 & 0 & 0 & 0 & 0 \\
\hline Maximum & 0.45 & 0.26 & 1.18 & 0 & 0.01 & 0.01 & 0 \\
\hline Average & 0.08 & 0.08 & 0.15 & 0 & 0 & 0 & 0 \\
\hline \multicolumn{8}{|c|}{ WEST BENGAL } \\
\hline Minimum & 0.003 & 0.15 & 0 & 0 & 0 & 0.15 & 0 \\
\hline Maximum & 0.017 & 0.47 & 0.598 & 0.66 & 0.11 & 0.59 & 0 \\
\hline Average & 0.01 & 0.25 & 0.17 & 0.29 & 0.03 & 0.26 & 0 \\
\hline \multicolumn{8}{|l|}{ ANDAMAN } \\
\hline Minimum & 0 & 0 & 0 & 0 & 0 & 0 & 0 \\
\hline Maximum & 10 & 91 & 33 & 50 & 10 & 10 & 0.5 \\
\hline Average & 1.82 & 8.97 & 2.54 & 4.23 & 0.85 & 0.77 & 0.05 \\
\hline \multicolumn{8}{|c|}{ LAKSHADWEEP } \\
\hline Minimum & 0 & 1.01 & 0.23 & 0 & 0 & 0.093 & 0 \\
\hline Maximum & 7.69 & 15.85 & 10.84 & 1.346 & 1.593 & 5.04 & 0 \\
\hline Average & 1.61 & 4.37 & 3.07 & 0.47 & 0.19 & 1.26 & 0 \\
\hline
\end{tabular}

$\left(150 \mathrm{~g} / \mathrm{m}^{2}\right)$ recorded from Karnataka. Discarded synthetic foot wears and plasto-foam slippers grouped under group ' $C$ ' registered highest mean of $57.87 \mathrm{~g} / \mathrm{m}^{2}$ from the beaches of Karnataka. Glass bottles as well as electric bulbs constituting ' $D$ ' group, mostly of alcoholic beverages and aerated drinks also registered highest mean of $68.15 \mathrm{~g} / \mathrm{m}^{2}$ from Goa although maximum values for $D$ group was $\left(650 \mathrm{~g} / \mathrm{m}^{2}\right)$ recoded from two beaches of Karnataka (Table 3).
Table 4. Colour code and the matching grades of beaches based on mean levels of litter $\left(\mathrm{g} / \mathrm{m}^{2}\right)$.

\begin{tabular}{llllllll}
\hline Mean levels & $<1$ & $1.1-10$ & $10.1-20$ & $20.1-50$ & $50.1-100$ & $>100$ \\
\hline Entire coastline & 51 & 122 & 36 & 17 & 7 & 21 \\
\hline Karnataka & 0 & 8 & 2 & 8 & 2 & 13 \\
\hline Kerala & 17 & 32 & 4 & 1 & 0 & 0 \\
\hline Goa & 0 & 5 & 3 & 2 & 0 & 5 \\
\hline Maharashtra & 12 & 22 & 4 & 0 & 0 & 0 \\
\hline Gujarat & 3 & 0 & 1 & 2 & 4 & 2 \\
\hline Tamil Nadu & 2 & 31 & 11 & 3 & 0 & 0 \\
\hline Lakshadweep & 0 & 5 & 4 & 1 & 0 & 0 \\
\hline Andhra Pradesh & 4 & 9 & 6 & 0 & 0 & 0 \\
\hline Odisha & 7 & 1 & 0 & 0 & 0 & 0 \\
\hline West Bengal & 3 & 2 & 0 & 0 & 0 & 0 \\
\hline Andaman & 3 & 7 & 1 & 0 & 1 & 1 \\
Nicobar & & & & & & \\
\hline
\end{tabular}

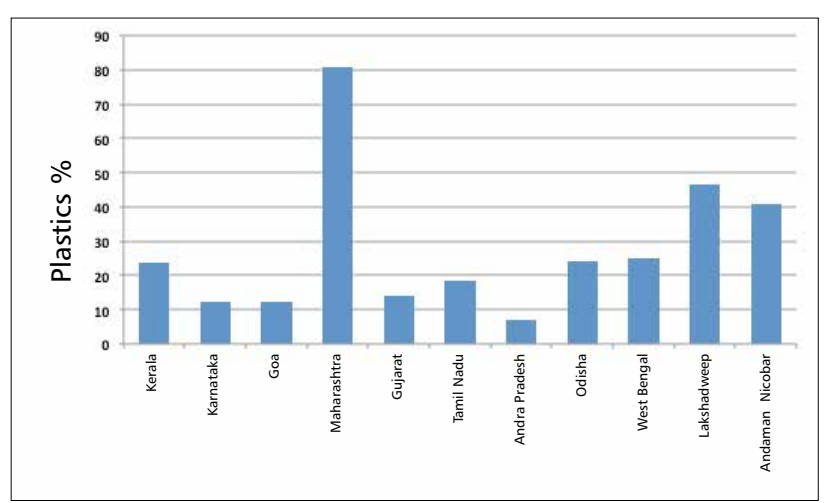

Fig. 2. Relative percentage of Plastics (B) in beach debris

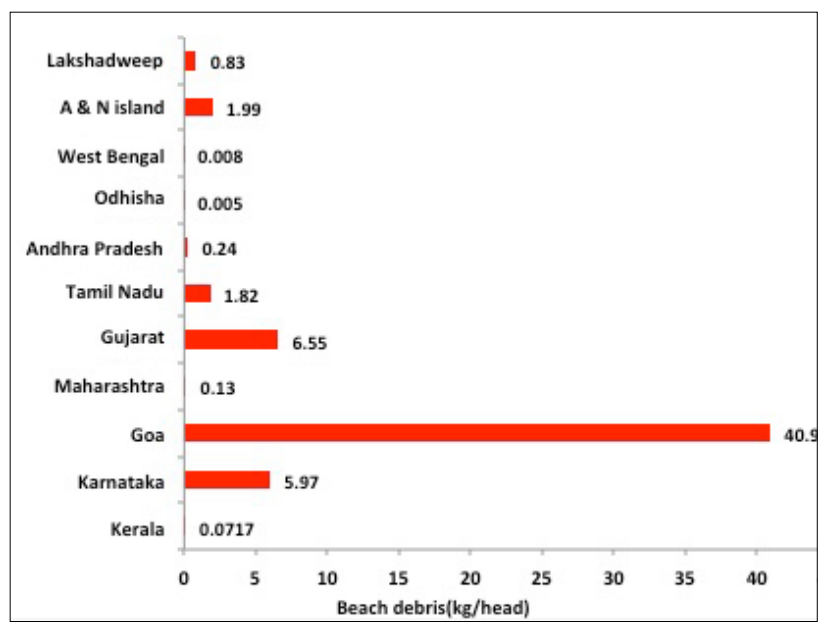

Fig. 3. Per capita share of beach debris among coastal population of Indian coastline

Electronic wastes 'E' such as parts of circuit chips, diodes, computer and mobile hardware parts, CDs, parts of battery operated toys, button cells etc. registered the highest mean of $0.85 \mathrm{~g} / \mathrm{m}^{2}$ from the Andamans although maximum values of $15 \mathrm{~g} / \mathrm{m}^{2}$ was reported from Andhra Pradesh. E-group debris 
was not recorded from Odisha and Goa coasts. The ' $F$ ' group comprising Styrofoam, PUF and similar insulators and thermocol floats recorded highest mean of $26.47 \mathrm{~g} / \mathrm{m}^{2}$ from Karnataka (Table 3). The relative percentage of mean values of group ' $B$ ' items (domestic and anthropogenic plastics) in beach debris along the Indian coast is given in Fig. 2 . The highest mean percentage of B group among debris was obtained from Maharashtra (81\%) followed by Andamans (47\%), while the national average was only $14 \%$. The lowest mean percentage of group $B$ debris was observed from beaches of Andhra Pradesh (7\%) followed by Karanataka and Goa (12\%). The two island Union Territories registered $40 \%$ (Lakshadweep) and $47 \%$ (Andamans) of B over the total debris.

Out of the total 254 beaches surveyed, 51 beaches were graded as very clean with green $\left(<1 \mathrm{~g} / \mathrm{m}^{2}\right)$ colour, 122 beaches were graded Clean and depicted by blue colour. The details are shown in Table 4. Beaches extremely clean $\left(<1 \mathrm{~g} / \mathrm{m}^{2}\right)$ were found in Kerala (17), Maharashtra (12), Tamil Nadu (2), Andhra Pradesh (4), Odisha (7) and West Bengal (3). Whereas, heavily littered beaches $\left(>100 \mathrm{~g} / \mathrm{m}^{2}\right)$ were found in Karnataka (13), Goa, Gujarat, and Andaman Island.

With reference to the coastal population as per the Marine Fisheries Census-2010 and without considering the visitors and tourists the per capita share of beach debris was estimated and Goa registered highest values $(40.97 \mathrm{~kg} / \mathrm{head})$ while Odisha coast registered the lowest values $(0.005 \mathrm{~kg} / \mathrm{head}$; Fig. 3$)$.

\section{Discussion}

This baseline information is based on one time sampling and the results presented represent a synoptic picture. The seasonal variations that could exist are not captured by this study. The results showed that litter became an integral part of beach ecosystem. The data also have some connection between beach litter and coastal urbanization /tourism activity, especially in Goa and Karnataka. It must be noticed that affluence of coastal population has a bearing on consumption of packaged products.

The results presented indicate that plastics make up the largest component of marine litter. Plastics being buoyant, they will be seen dispersed in the water column over long distances and when they settle at the bottom, will persist in marine sediments for many years (Hansen, 1990; Goldberg, 1995; 1997). Plastic carry bags as an omnipresent and widespread pollutant, plastic debris may cause wider ecosystem effects which result in loss of productivity and implications for trophic interactions. All the seven species of turtles are known to ingest or become entangled in marine debris (Sarah et al., 2016). Ingestion can cause intestinal blockage and internal injury, dietary dilution, malnutrition, and increased buoyancy which in turn can result in poor health, reduced growth rates and reproductive output or death. Over the past, pollution by PCBs has alarmingly increased in marine food webs most particular on seabirds (Ryan et al., 1988). Plastics are known to leach PCBs into water and sediment over a period of time. Inside the plastic ingested animals, adsorption of PCBs is extensively possible (Teuten et al., 2009). It is estimated that (Clark, 1997) ships discard more than 6.5 million tonnes of plastics per year and hence all vessels should comply with the MAR POL regulations. Top five nations of plastic pollution are China (30\%) Indonesia, Phlippines, Vietnam and Sri Lanka (Jenna et al., 2015). If India did not check the production as well as manage the disposal of plastic products our country would soon figure at sixth position in the aforementioned list.

The increasing levels of e-waste generation in India in the recent years have been a matter of serious concern. India has emerged as the second largest mobile phone market and approximately $25 \%$ of the handsets become e-waste every year. Due to this, India has become the fifth largest producer of e-waste (1.85 million metric tonnes/year) in the world. (The Hindu, New Delhi, 25-5-2016). The prevalence of plastic litter in Lakshadweep and in Andamans was higher than that in majority of States is a matter of concern. Considerable part of this litter can be traced from the neighbouring nations or from the ship discards (Dharani et al., 2003). The limited land endowment in these archipelagos does not permit land based dumping. There are certain cultural aspects which make the community unaware of the systems response to the present trend of consumption. A campaign creating awareness and education is immediately needed to save the vulnerable island ecosystem from unexpected setbacks.

Grading the beaches with colour code would help the planners and the policy makers to increase the number of $A$ grade or green beaches every year, while stringent measures can be taken to reduce the number of extremely polluted beaches. The results pertaining to per capita share support the need and responsibility for every citizen to reduce the use of plastics and to stop littering on beaches. For control of litter a multipronged approach is necessary and by innovative thinking communities can evolve feasible measures and policy interventions. The plastic litter being terrestrial in origin, all control measures must start form the land. There are certain important source (entry points) for marine debris, namely local rivers and canals connected to sea. The ideal approach would be to tackle the issue from both the production as well as disposal level. Sewage ducts, canals opening to large streams, rivers or sea should have a sort of filter- barrier to check the entry of plastics and other debris items.

Creating awareness through regular coastal clean ups and certain degree of legislation are the key elements for reducing beach litter. Reports confirm that increasing public awareness 
and through educational campaigns, beaches in Wales showed marked reduction in litter quantities since 2000 (Williams et al., 2005; 2014). Similarly studies in India confirm the significant reduction in beach litter after creating awareness to the coastal fishers in Dakshin Kannada coast, Mangalore (Bindu et al., 2013). The following steps, wherever possible could be adopted depending on the specific needs of the locality.

- The age old three 'R's: Reduce (both production and use), Reuse, Recycle is the most important approach.

- Inculcate the habit of using alternate eco-friendly material for frequently consumed item such as stationery, packaging etc.

- Establish a garbage collection and disposal mechanism and provide dust bins in all public places.

- Inculcate the habit of segregation of waste from domestic sources into bio-degradable, metallic and plastic items with proper incentive for doing such activities.

- Educate about this domestic waste disposal discipline among the residents and community.

- Establish proper incentives for reducing the use of plastics such as carry bags, disposable plates etc. Or such items could be priced to a level where the consumers would feel discouraged to use it.

- Wherever items like bottled water is sold, facilities for use of refillable bottles rather than disposable bottles must be promoted.

- In the long-run a sort of plastic tax should be imposed on major consumer packages which should be channelled to mitigation of plastic menace.

\section{Acknowledgements}

The authors are thankful to the Director, CMFRI, Kochi; Head of FEM Division and the Scientists in Charge of their respective Research Centres of CMFRI for providing facilities, support and encouragements.

\section{References}

Allsopp, M., A. Walters, D. Santillo and P. Johnston. 2009. Plastic debris in the World's Oceans. Green Peace International, Amsterdam, Netherlands $44 \mathrm{p}$.

Bindu Sulochanan, S. Lavanya and S. Kemparaju. 2013. Influence of river discharge on deposition of marine litter. Mar. Fish. Infor. Serv: T \& E Series. 216: 27-29.

Bindu Sulochanan, G. S. Bhat, S. Lavanya, A. P. Dineshbabu and P. Kaladharan, 2014. Preliminary assessment of ecosystem process and marine litter in the beaches of Mangalore. Indian J. Geo-Mar. Sci. 43 (9): 1-6.

Clark, R. B. 1997. Marine Pollution. Clarendon Press, Oxford.

Derraik, J. G. B. 2002. The pollution of the marine environment by plastic debris: a review. Mar. Pollut. Bull., 44: 842-852.
Dharani, G., A. K. A. Nazar, R. Venkatesan and M. Ravindran. 2003. Marine debris in Great Nicobar. Curr. Sci., 85: 574-575.

Ganesapandian, S., S. Manikandan and A. K. Kumaraguru. 2011. Marine litter in the northernpart of Gulf of Mannar, southeast coast of India. Res. J. Environ. Sci., 5: 471-478.

Goldberg, E. D. 1995. Emerging problems for the coastal zone in the 21st century. Mar. Pollut. Bull., 31 (4-12):152-158.

Goldberg, E.D. 1997. Plasticizing the seafloor: an overview. Environmental Technology 18:195-202.

Gregory, M. R. 2009 Environmental implications of plastic debris in marine settings entanglement, ingestion, smothering, hangers-on, hitch-hiking and alien invasions. Phil. Trans. R. Soc. B., 364:2013-2025. (doi:10.1098/ rstb.2008.0265)

Hansen, J. 1990. Draft position statement on plastic debris in marine environments. Fisheries15:16-17.

Hong, S., J. Lee, D. Kang , H.W. Choi and S. H. Ko, 2014. Quantities, composition and sources of beach debris in Korea from the results of nationwide monitoring. Mar. Polutl. Bull., 84: 27-34.

ICMAM, 2010. Report-Integrated Coastal and Marine Area Management Project, Ministry of Earth Sciences, Government of India.

Jayasiri, H. B., C. S. Purushothaman and A. Vennila. 2013. Plastic litter accumulation on high-water strandline of urban beaches in Mumbai, India. Environ. Monit. Assess., 185:7709-7719.

Jenna R. J., R. Geyer, C. Wilcox, T. R. Siegler, M. Perryman, A. Andrady, R. Narayan and K. L. Law. 2015. Plastic waste inputs from land into the ocean. Science, 347(6223):768-771.

Kaladharan, P., K. Vijayakumaran, V. V. Singh, P. S. Asha, Bindu Sulochanan, P. K. Asokan, K. K.Valsala, S. Veena, L. Jayasankaran and H. M. Bhint. 2012. Assessment of certain Anthropogenic Interventions and their Impacts along the Indian Coastline. Fish. Technol., 49: 32-37.

Marine Fisheries Census. 2010. Marine Fisheries Census, Part 1 India. Government of India, Ministry of Agriculture, DAHDF and ICAR- CMFRI, Kochi 98 p.

OSPAR., 2010. Guideline for Monitoring Marine Litter on the Beaches in the OSPAR Maritime area, OSPAR Commisssion, Edition 1.0.

Rochman, C. M., E. Hot, T. Kurobe, and S. J. Teh. 2013. Ingested plastic transfers hazardous chemicals to fish and induces hepatic stress. Scientific Reports 3.Article number:3263 (doi:http://dx.doi.org/10.1038/srep03263).

Ryan, P. G. 1988. Intraspecific variation in plastic ingestion by seabirds and the flux of plasticthrough seabird populations. Condor. 90:446-452. (doi:10.2307/1368572)

Sarah E. N., E. M. Duncan, A. C. Broderick, T. S. Galloway, M. H. Godfrey, M. Hamann, P. K. Lindeque, and B. J. Godley. 2016. Plastic and marine turtles: a review and call for research. ICES Journal of Marine Science, 73(2): 165-181. doi:10.1093/ icesjms/fsv165 Downloaded from http://icesjms.oxfordjournals.org/ at Central Marine Fisheries Research Institute on January 24, 2016.

Sridhar, K. R., B. Deviprasad, K. S. Karamchand and R. Bhat, 2009. Plastic litter along the beaches of Karnataka, southwest coast of India. Asian J. Water Environ. Pollut., 6: 87-93.

Teuten, E. L., M. J. Saquing, D. R. U. Knappe, M. A. Barlaz, S. Jonsson, A. Bjo "rn, S. J. Rowland, R. C. Thompson, T. S. Galloway, R.Yamashita, D. Ochi , Y. Watanuki, C. Moore, P. H. Viet, T. S. Tana, M. Prudente, R. Boonyatumanond, M. P. Zakaria , K. Akkhavong, Y. Ogata, H. Hirai, S. Iwasa , K. Mizukawa, Y. Hagino, A. Imamura, M. Saha and H. Takada. 2009. Transport and release of chemicals from plastics to the environment and to wildlife. Phil. Trans. R. Soc. B., 364:2027-2045 doi:10.1098/rstb.2008.0284

Thompson, R. C., C. J. Moore, F. S. Vom Saal and S. H. Swan. 2009. Plastics, the environment and human health: current consensus and future trends. Phil. Trans. R. Soc. B., 364: 2153-2166. (doi:10.1098/rstb.2009.0053).

UNEP, 2009. Marine litter: A global challenge. Nairobi, Kenya: United Nations Environment Programme, 232p.

Williams, A. T., M. Gregory and D. T. Tudor, 2005. Marine Debris - Onshore, Offshore,Seafloor. In: Schwartz, M.L. (Ed.), Encyclopaedia of Coastal Processes. Springer, pp. 623-628.

Williams, A. T., P. Randerson and O. A. Alharbi, 2014. From a millennium base line to 2012: Beach litter changes in Wales, Mar. Pollut. Bull., 84:17-26. 